\title{
March 1924
}

\section{Vol. XXXIX., No. 3}

\section{The Journal of}

Laryngology and Otology

EDITED BY

A. LOGAN TURNER AND J. S. FRASER

\section{Contents}

Osseous and Cartilaginous Formations in the TONSILS

- IRWIN MOORE Tonsillectomy in School Clinics . . . James Kerr Love A Note on the Directoscope . - . . . C. G. Russ Wood The Course of Endoscopy in Chevalier Jackson's SERVICE

V. E. NEGUS

Societies' Proceedings :-

Royal Society oe Medicine-Section of Laryngology.

Scottish Society of Otology and LaRyngology.

Abstracts :-

Ear. The Pharynx. Larynx. Esophagus.

Reviews of Books. General Notes.

\section{Edinburgh: Oliver and Boyd London : 33 Paternoster Row}


"We have experimentally proved that Listerine is a powerful antiseptic, preventing the development of bacteria and decomposition of vegetable infusions."-British Medical Journal, May 3, 1890.

\section{A safe, non=poisonous, unirritating antiseptic solution}

LISTERINE is particularly useful in the treatment of abnormal conditions of the mucosa, and admirably suited for a wash, gargle, or douche, in catarrhal conditions of the nose and throat.

LISTERINE in proper dilution may be freely and continuously used without prejudicial effect, either by injection or spray, in all the natural cavities of the body.

LISTERINE embodies a two-fold antiseptic effect, in that after the evaporation of its volatile constituents-thyme, eucalyptus, mentha, gaultheria, and ethyl alcohol-a film of boracic and benzoic acids remains upon the surface to which Listerine bas been applied, affording more prolonged antiseptic protection.

LISTERINE is a trustworthy surgical dressing; it has no injurious effect upon the tissues in which the healing process is going on.

LISTERINE in teaspoonful doses will often afford relief in fermentative dyspepsia, and is largely prescribed, with excellent results, in the various forms of diarrhcea, occurring in infants and adults.

LISTERINE literature, including special pamphlets upon Respiratory Diseases, may be had, by physicians, upon application to

\section{LAMBERT PHARMACAL COMPANY 2 Ior Locust Street

British Agents :

S. Maw, Son \& Sons, 7 Aldersgate St., London, E C. 


\title{
The Journal of Laryngology and Otology
}

(Founded in 1887 by Morell Mackenzie and Norris Wol.FendeN)

\author{
EDITED BY \\ A. LOGAN TURNER ANd J. S. FRASER \\ ASSISTED BY
}

DOUGLAS GUTHRIE AND IRWIN MOORE

1. Original Articles are accepted on the condition that they have not been published elsewhere.

2. Manuscripts should be typewritten, on one side only of the paper, and well spaced.

3. Galley proofs and engraver's proofs of illustrations are sent to the author. Corrections, which should be kept to a minimum, must be clearly marked and no additional matter should be added.

4. The order for reprints should be sent when returning galley proofs, and for this purpose special forms are supplied, on which the price of the reprints is stated.

5. Authors of Original Communications on Oto-Laryngology in other Journals are invited to send a copy, or two reprints, to the Journal of Laryngology. If they are willing, at the same time, to submit their own abstract (in English, French, Italian, or German) it will be welcomed.

6. Editorial Communications should be addressed to "EDIToRs, Joumal of Laryngology, c/o Messrs OLIVER AND BOYD, Tweeddale Court, Edinburgh."

7. The Annual Subscription is Forty Shillings, post free, and is payable in advance.

8. Single copies of back numbers, both of the present and the previous series, are on sale at Four Shillings each.

9. An Annual Subscription can be commenced with any number of the Journal, and the preceding numbers of the current year can be purchased at Four Shillings each.

\section{UNITED STATES OF AMERICA}

Orders for this Journal, for single parts or yearly subscriptions, can be sent either through a local bookseller, or to Messrs G. E. STECHERT \& Co., 3I·33 East Ioth Street, New York. 


\section{CONTENTS}

Osseous and Cartilaginous Formations in the Tonsils. Irwin Moore, M.B., C.M. Edin. . . . . . . . . . 117

Tonsillectomy in School Clinics. James Kerr Love, M.D.,

F.R.F.P.S. Glas. $\quad . \quad$. $\quad$. $\quad$. $\quad . \quad$. $\quad 135$

A Note on the Directoscope. C. G. Russ Wood, F.R.C.S. . . I4I

The Course of Endoscopy in Chevalier Jackson's Service. V. E.

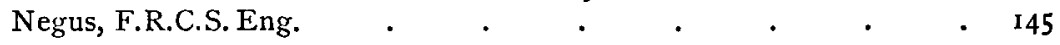

Societies' Proceedings :-

Royal Society of Medicine-Section of Laryngology . . . 150

Scottish Society of Otology and Laryngology $\quad . \quad$. $\quad . \quad 157$

ABstracts :-

Ear

The Pharynx

Larynx .

Esophagus

REVIEWS OF BOOKS

General Notes

\section{A D RE N A L I N}

The hæmostatic and blood-pressure-raising principle of the suprarenal gland, as first isolated in 1900 by TAKAMINE, and placed on the market in January, 1901, by PARKE, DAVIS \& CO.

\section{ADRENALIN CHLORIDE SOLU- TION, 1 in 1000. \\ Employed as a hrmostatic in epistaxis and surgical procedures, and as a constringent in nasal occluston. Administered hypodermi- cally in asthma, and orally in pertussts. \\ ADRENALIN INHALANT. \\ An oily solution of Adrenalin with Chloretone for use as a spray or swab in coryza, hay fever, laryngitis, pharyngitis, tousillitis, aphonia, odema, etc. \\ ADRENALIN THROAT \\ LOZENGES. \\ Contain Adrenalin, diamorphine, red gum, and ipecacuanha. Astringent, sedative, and expectorant. Useful in pharyngitis, tonsil- litis, gingivitis, etc. \\ ADRENALIN OINTMENT, aIso ADRENALIN \& CHLORETONE OINTMENT. Employed in coryza, rhinitis, hay fever, and
nasal obstruction.}

Further particulars will be sent on request by

\section{ADRENALIN TABLETS.}

Two strengths, for solution in 5 minims or 1 c. c., respectively, of sterile distilled water to form 1 in 1000 solution.

\section{ADRENALIN AND BENZAMINE} (EUCAINE) TABLETS.

One tablet in 1 to 5 c.c. of sterile distilled water forms a local ariæsthetic and ischæmıc solution for use in minor surgery.

\section{ADRENALIN}

TABLETS.

Two strengths. For preparing ischæmic and analgesic solutions for infiltration anrest hesia.

\section{" CODRENINE."}

A solution containing $1 / 1000$ grain of Adresalin ehloride and $1 / 3$ grain of cocaine hydrochloride in each c.c. For local anæsthesia.

\section{GEUDRENINE,"}

A solution containing 1/2000 grain of Adrenalin chloride and $1 / 6$ grain of benzamine (eucaine) hydrochloride in each c.c. For use in minor surgery.

\section{Parke, Davis \& Co., 50 Beak Street, London, w.1}

